\title{
Karaciğer hücreleri ve organoidlerin üç boyutlu kültürlerinde kullanılmak üzere geliştirilmiş biyomalzemeler
}

\author{
Gamze Demirel ${ }^{1}$ iD
}

${ }^{1}$ Maltepe University, Cancer and Stem Cell Research and Application Center, 34854, Istanbul, Turkey

$\ddot{O} z$

Doku mühendisliği ve biyomühendislik çalışmaları başta olmak üzere biyoloji ve kimya gibi temel bilimlerin son zamanlarda üzerinde odaklandığı disiplinlerarası bir çalışma olan 3 boyutlu (3B) biyobasım tekniği en yenilikçi teknolojilerden biridir. 3 boyutlu biyobasım, yaralı veya hastalıklı doku ve organları biyolojik olarak taklit edebilecek (biomimetik) doku ve organların yapımında çeşitli uygulamalara sahip gelişmekte olan bir teknolojidir. Bu yöntemde hücreler, büyüme faktörleri ve biyomalzemeler birleştirilir ve hibrit bir biyomalzeme elde edilir. Biyomalzemeler vasıtasıyla canlı hücreler ile katman katman, istenilen şekil, miktar ve fonksiyonda hücre iskeletleri (scaffold) üretilebilir. Özellikle karaciğer gibi karmaşık dokuları oluşturmak için biyobasım tekniği ile doku iskeleleri oluşturmak oldukça önemli bir yaklaşımdır. Hem doğal hem de sentetik kökenli polimerlerden yapılan biyo bağlantılar, karaciğer gibi yumuşak dokulara baskı uygulanması noktasında avantaja sahiptir. Bu derlemede özellikle hepatositler üzerine yapılan çalışmalar incelenmiş ve derlenmiştir.

Anahtar kelimeler: 3 boyutlu (3B) biyobasım; biyomalzemeler; doku mühendisliği; karaciğer hücreleri; organoidler

\section{Developed biomaterials for use in three dimensional cultures of liver cells and organoids}

\begin{abstract}
The 3D bioprinting technique, which is an interdisciplinary study on which basic sciences such as biology and chemistry, especially tissue engineering and bioengineering studies, has recently focused on, is one of the most innovative technologies. 3D bioprinting is an emerging technology with various applications in the construction of tissues and organs that can biologically mimic injured or diseased tissues and organs (biomimetic). In this method, cells, growth factors and biomaterials are combined and a hybrid biomaterial is obtained. By means of biomaterials, cell scaffolds of desired shape, quantity and function can be produced layer by layer with living cells. Creating tissue scaffolds with bioprinting technique is a very important approach, especially to create complex tissues such as liver. Biolinks made from polymers of both natural and synthetic origin have the advantage of applying pressure to soft tissues such as the liver. In this review, studies on hepatocytes were examined and compiled.
\end{abstract}

Keywords: 3 dimensional (3D) bioprinting; biomaterials; liver cells; organoids; tissue engineering

\footnotetext{
* Sorumlu yazar.

E-mail: gamzedemirel@maltepe.edu.tr (G. Demirel).

https://doi.org/10.51753/flsrt.982821 Yazar katkılar1

Geliş tarihi 14 Ağustos 2021; Kabul tarihi 27 Kasım 2021

Çevrimiçi yayın 24 Aralık 2021

2718-062X ๔ 2021 This is an open access article published by Dergipark under the CC BY license.
} 


\section{Giriş}

Karaciğer, kandan amonyağın uzaklaştırılması ve metabolik işlevlerin yerine getirilmesinde rol oynayan önemli bir organdır (Wells, 2008). Karaciğer aynı zamanda parankimal (hepatositler) ve parankimal olmayan hücreleri de içeren kompleks bir yapıdadır. Hepatositler, karaciğer fonksiyonlarının çoğunu yerine getiren farklılaşmış epitel hücrelerdir. Karaciğer hücreleri hem homotipik hem de heterotipik hücrehücre ve hücre-ekstraselüler matriks (ECM) etkileşimleri sergilemektedir. Hepatositler, boşluk bağlantıları, sık1 bağlantılar, ara bağlantılar ve dezmozomlar yoluyla birbirleriyle yoğun bir şekilde etkileşime girerler. Hepatositlerin diğer parankimal olmayan hücrelerle etkileşimi, normal karaciğer fonksiyonunun sürdürülmesinde önemli bir rol oynamaktadır. $\mathrm{Bu}$ etkileşimlere esas olarak parakrin sinyallemesi aracilık etmektedir (Elvevold ve ark., 2008; Turner ve ark., 2011). ECM, hepatositlerin ve parankimal olmayan hücrelerin farklılaşmış fenotiplerinin ekspresyonunu kontrol etmektedir. ECM bileşenleri, hücre yapışması ve mimarisi için olduğu kadar hücre iskelet yapısının bakımı için de oldukça önemlidir. Hastalıklı karaciğer durumunda, ECM normalden sirotik aşamaya doğru sertleşir ve karaciğer hastalığının tespiti için bir belirteç olarak işlev görür (Bogert ve LaRusso, 2007). Karaciğer hastalıkları ya kalıtsaldır ya da sonradan edinilmiştir. Bu gibi karaciğer hasarları ve karaciğerin sınırlı rejenerasyon kapasitesi biyo-yapay organ üretiminin geliştirilmesine yol açmıştır. Bu alanda çalışmak doku mühendisliği stratejilerinin entegrasyonunu gerektirir ve bu da üç boyutlu (3B) basım teknolojilerinden büyük ölçüde etkilenir.

Biyolojik basım, hücreleri hücre uyumlu malzemelerle (örn. polimerler veya hidrojeller) ve sertleştirme işlemleriyle (örn. foto çapraz bağlama) birlikte eşzamanlı olarak yazdıran bir 3 boyutlu basım işlemi olarak tanımlanabilir (Lauschke ve ark., 2016). Biyomalzemeler, hücreler ve biyoaktif molekülleri, canlı ve işlevsel doku yapılarını oluşturmak için istenen tasarım ve konumu sağlayabilir. 3B biyobasım teknikleri, karmaşık dokuların geliştirilmesi için umut verici niteliklere sahiptir. Üç boyutlu basım teknolojileri ile hepatik yapılar üretilebilir. Sentezlenen bu ürünler uzun süreli canlılık, işlevsellik ve mekanik stabilite sağlayabilir (Wells, 2008). Bu derlemede, üç boyutlu hepatorganoidler için kullanılan biyomalzemelere, doğal ve sentetik basım tekniklerine ve farklı polimerlere kısa bir giriş yapılmıştır. Üç boyutlu biyobasım ile ilgili son yapılan çalışmalara odaklanılarak güncel yayınlar derlenmiştir.

\section{3 boyutlu biyobasım ve ön koşulları}

Üç boyutlu basım, bilgisayar programları aracılığı ile X, Y ve $Z$ koordinat düzlemlerinde farklı malzemelerin katman katman eklenmesiyle karmaşık formların yüksek hassasiyetle üretilmesini sağlar (Murphy ve Atala, 2014; Munaz ve ark., 2016). Üç boyutlu biyobasım, hasarlı doku ve organları onarmak veya değiştirmek için doku iskeleleri üretmek amacıyla kullanılır. Farklı 3B basım teknikleri türleri mevcuttur. Genel olarak ekstrüzyon biyobasım, mürekkep püskürtmeli basım, lazer destekli basım ve stereolitografik basım olarak sinıflandırılabilir (Tamay ve ark., 2019). Ekstrüzyon biyoyazıcı, en yaygın kullanılan 3B biyobasım yöntemidir. Piston, sürekli bir kuvvetle uygulandığında, ayrı damlacıklar yerine kesintisiz silindirik çizgileri çıkarabilir. Yüksek viskoziteli malzemeler için uyumluluk sağlar. Neredeyse tüm biyo-bağlantılar çeşitli malzemeleri aynı anda makul bir maliyetle yazdırabilir. Bu yöntemin temel avantaj, herhangi bir viskoz malzeme kullanarak büyük 3 boyutlu yapılar üretebilmesidir. Dezavantaj1 ise işlem sırasında yüksek mekanik strese maruz kalınması nedeniyle hücre canlılığının engellenmesidir (Murphy ve Atala, 2014).

Kullanılacak polimer ile biyo-basım yapılabilmesi için uyulması gereken belirli kriterler vardır. En önemlisi her tür biyomalzeme için geçerli olan polimerin biyouyumluluğudur. Polimer, hücre için toksik olmamalıdır, hücrelerin basım sonrası proliferasyonu ve/veya genişlemesi için yapısal destek ve yüzey sağlamak üzere polimerin sito-yapışkan olması önemli olabilir. Diğer önemli özellik ise polimer çözeltisinin viskoelastik veya reolojik özelliklerinden büyük ölçüde etkilenen polimerin basılabilirliğidir ve bu da çözelti içindeki polimer konsantrasyonuna bağlıdır (Wang ve ark., 2015; 2018; Wang, 2019a). Genel anlamda, yüksek viskoziteye sahip bir polimer çözeltisinin daha kararlı ürünler sentezlemesi beklenmektedir. Biyomalzemenin bir diğer önemli özelliği ise bozunma kimyası ve basılı yapının sertliğidir. Çünkü her ikisi de istenilen ilgili dokunun özelliklerine uygun olmalıdır (Blaeser, 2016; Panwar ve Tan, 2016). Biyolojik bozunabilirlik, doku fonksiyonlarının yenilenmesi ile bağlantılıdır. Sertlik ise proliferasyon ve farklılaşma gibi çoklu hücresel aktivitelerle ilişkilidir ve böylece ilgili dokunun yenilenmesine katkıda bulunur (Kolesky ve ark., 2016).

\section{Karaciğer hücrelerinde biyomalzeme olarak kullanılan polimerler}

Polimerler, kovalent bağlarla bağlanmış tekrar eden monomer birimlerini oluşturan büyük zincirlerdir (Causa ve ark., 2006). Kökenlerine göre polimerler ya doğal ya da sentetiktir (Tablo 1). Doğal polimerler, bitki ve hayvan hücre dişı matrislerinde bol miktarda bulunur ve bu nedenle dokuların/organların hücre dışı matrisine büyük oranda benzerlik gösterir. Bu benzerlik biyomalzemelerin birincil tercih sebebidir. Tercih sebepleri sırasıyla biyouyumlu olması, biyolojik olarak parçalanabilir olması, toksik olmaması, nemi muhafaza etmesi ve belirli fizyolojik koşullar altında anjiyogenez, nörojenez, lenfogenez, organojenez ve doku/organ olgunlaşmasını desteklemesidir (Hospodiuk ve ark., 2017; Gopinathan ve Noh, 2018).

Doğal polimerler, biyolojik olarak sentezlenen, sentetik polimerler ise laboratuvarlarda ve çeşitli endüstriyel iş kollarında insan yapımı üretilen malzemelerdir. Özelliklerini önceden tanımlanmış koşullar gösterir. Sentetik polimerlerin temel avantajı, örneğin dokuların/organların belirli özelliklerini taklit etmek gibi uygulamanın ihtiyacına göre tasarım yapma imkânı sağlamasıdır. Ayrıca, biyomalzemelerin fizikokimyasal özelliklerinin belirli kimyasal modifikasyonlarla uyarlanmasına ve ayarlanmasına da izin verirler (Wang, 2019b). Bu avantajlar, monomerlerin zincir uzunluğu, moleküler ağırlığı, dallanması, geometrisi ve dağılımı üzerinde kontrol sağlar ve böylece polimere istenen özellikler kazandırılabilir.

\section{Doğal polimerler}

Doğal polimerler, özellikleri nedeniyle yumuşak dokularda kolay çalışılabilmesi ile sıklıkla tercih edilir. Pek çok doğal polimer hepatorganoidlerde biyomürekkep olarak kullanılmaktadır. Jelatin ve aljinat, 3B hepatik biyobasım için yaygın olarak kullanılır. Tek zincirli bir polimer olan jelatin, balık, sığır veya domuz gibi farklı hayvanların dokularından ekstrakte edilen 
Tablo 1

Karaciğer hücrelerinin 3B biyobasımı için kullanılan temel biyomalzemeler (Wang ve ark., 2015; Panwar ve Tan, 2016; Sarkar ve ark., 2020).

\begin{tabular}{|c|c|c|c|c|c|}
\hline Polimer & Biyomolekül Sınıfı & $\begin{array}{l}\text { Hücre ile } \\
\text { Bağlanma }\end{array}$ & Suda Çözünürlük & Biyobozunurluk & Diğer Önemli Özellikler \\
\hline \multicolumn{6}{|c|}{ Doğal Polimerler } \\
\hline Jelatin & Protein/Peptit & Evet & Çözünür & Evet & $\begin{array}{l}\text { Daha düşük sıcaklıklarda } \\
\text { kendi kendine jelleşme }\end{array}$ \\
\hline Aljinat & Polisakkarit & Hayır & Çözünür & Evet & Katyonik jelleşme \\
\hline Agaroz & Polisakkarit & Hayır & Yüksek sıcaklıkta çözünür & Evet & Olağanüstü mekanik destek sağlar \\
\hline Kolajen & Protein & Evet & Düşük pH’ta çözünür & Evet & $37^{\circ} \mathrm{C}$ 'de yüksek jelleşme süresi \\
\hline Selüloz & Polisakkarit & Hayır & Çözülmez & Hayır & Uzun süreli uygulama için verimli \\
\hline Kitosan & Polisakkarit & Hayır & Düşük pH’ta çözünür & Evet & $\begin{array}{c}\text { Zayıf jelleşme ve mekanik } \\
\text { mukavemet }\end{array}$ \\
\hline \multicolumn{6}{|c|}{ Sentetik Polimerler } \\
\hline${ }^{1}$ PEG & Polieter & Hayır & Çözünür & Hayır & $\begin{array}{l}\text { Mekanik mukavemet } \\
\text { üzerinde etkili kontrol }\end{array}$ \\
\hline${ }^{2} \mathbf{P C L}$ & Polyester & Hayır & Çözülmez & Evet & Sert yapılar üretir \\
\hline${ }^{3}$ PLGA & Polyester & Hayır & Suda bozulur & Evet & - \\
\hline \multicolumn{6}{|c|}{ Hücresizleștirilmiş Matris } \\
\hline $\begin{array}{l}\text { Karaciğer } \\
{ }^{4} \text { dECM }\end{array}$ & $\begin{array}{c}\text { Proteinler, polisakkaritler, } \\
\text { glikoproteinler, proteoglikanlar }\end{array}$ & Evet & Çözünür & Evet & $\begin{array}{l}\text { Doğal kimyasal yapıyı ve } \\
\text { mikro geometriyi korur }\end{array}$ \\
\hline
\end{tabular}

${ }^{1} \mathrm{PEG}$ : polietilen glikol, ${ }^{2} \mathrm{PCL}$ : polikaprolakton, ${ }^{3} \mathrm{PLGA}$ : poli (laktik asit-ko-glikolik asit), ${ }^{4} \mathrm{dECM}$ : hücresizleştirilmiş hücre diş1 matris.

kolajenin üçlü sarmal yapısının kısmi hidrolizinden ve kırılmasından elde edilmektedir. Jelatin, biyolojik tamponlarda ve hücre kültürü ortamında yüksek oranda çözünür olup, 3B baskı için hücre ve biyoaktif madde yüklü biyolojik bağlantıların hazırlanmasına destek verir (Panwar ve Tan, 2016). Doğal polimer olan jelatinin yüksek düzeyde biyouyumlu ve sitouyumlu olması ve immünojenik olmaması ideal bir polimer olduğunu gösterir. Jelatin, tüm hücre tipleri için tamamen toksik değildir ve in vivo ortamda sitokin aktivasyonu ve inflamasyon gibi ters bir immün yanıta neden olmaz (Liu ve ark., 2018). Aynı zamanda, bağlanma için hücre zarı üzerindeki integrinler tarafından tanınan tripeptid motifi Arg-Gly-Asp içerir. Colosi ve ark. (2016), yaptıkları çalışmada jelatin ve aljinat bazlı biyomürekkep ile basılan üç boyutlu hücre iskeleleri üzerine HUVEC hücreleri mükemmel yapışma sergilemiştir ve ayrıca oluşturulan hücre iskelesinde kullanılan aljinat bazlı biomürekkep hücre göçünü ve hizalanmasını desteklediğini göstermiştir.

Wang ve ark. (2008) ve yanı sira Gaetani ve ark. (2015), sırasıyla jelatin bazlı hidrojel ve basılı yapı üzerine karaciğer ve kardiyak progenitör hücrelerin daha iyi yapıştığını gösteren çalışmalar yapmışlardır. Jelatin biyolojik olarak parçalanabilir ve biyoyazıcılar ile basılabilir. $\mathrm{Bu}$ durum jelatini biyoink seçiminde mükemmel bir polimer yapar. Xiao ve ark. (2011), yaptıkları çalışmada ise jelatin bazlı hidrojellerin \%80'lik degradasyon oranına sahip olduğunu göstermiş̧lerdir.

Biyobasım için jelatin çözeltisinin basılabilirliği viskozite oranı ile belirlenir ve bu da polimer konsantrasyonuna ve çözelti için bazı katkı maddelerine bağlıdır. Bu kriterler hücreler, biyoaktif maddeler, diğer biyomateryaller (karışımlar ve kompozitler için) vb. olabilecek diğer çeşitli maddelere bağlıdır (Gauvin ve ark., 2012).

Kang ve ark. (2016) tarafindan üretilen hücre iskelesi ise biyomürekkep olarak kullanılan biyomalzemeler jelatin, hyaluronik asit, fibrinojen, gliserol ve hücrelerin bir kompozitini içermiştir. $\mathrm{Bu}$ çalışmada daha düşük jelatin konsantrasyonu, basılı yapının stabilitesinin azalmasına rağmen daha iyi hücre yaşayabilirliği sergilemiştir. Baskı sonrası hücre iskelesinin stabilitesi hem fiziksel jelleşmeye hem de kullanılan kimyasalın çapraz bağlanma derecesine bağlıdır.
Jelatin, zayıf fiziksel çapraz bağlanma ile düşük sıcaklıklarda kendi kendine jelleşme yeteneğine sahiptir, ancak basıldığında zayıf mukavemetli yapılar oluşturur. Basılı yapıları stabilize etmek için bazı kimyasal çapraz bağlama yöntemleri kullanılabilir. En yaygın örneklerden biri, jelatinin amino asit yan zincirleri ile Schiff' in baz oluşumu yoluyla glutaraldehit ile çapraz bağlanmadır. İdeal bir jelatin konsantrasyonu ve çapraz bağlama yöntemi, istenen mekanik mukavvamiyet ve biyouyumluluğa sahip hepatik hücre iskeleleri oluşturulmasını sağlayacaktır (Gauvin ve ark., 2012). Bu gibi çapraz bağlanma yöntemlerinin yanı sıra, foto çapraz bağlama ayrıca jelatinin metakriloilasyonu ile jelatin metakrilatı (GelMA) oluşturur. Metakriloil gruplar1, jelatinin amino asit yan zincirlerinin amin ve hidroksil gruplarına dahil edilir. GelMA'nın çapraz bağlanması, suda çözünür bir foto başlatıcı eklenmesi ve ardından UV ışınına maruz bırakılmasıyla sağlanabilir (Wang, 2019a).

En yaygın kullanılan foto başlatıcılar, $5 \mathrm{mg} / \mathrm{ml}$ 'lik bir sulu çözünürlüğe sahip olan 2-hidroksi-1-[4-(2-hidroksietoksi) fenil]-2-metil-1-propanon içerir (Yue ve ark., 2015). Biyobasım ile elde edilen hücre iskeleleri; GelMA yapısının sertliği ve hücre canlılığına, polimer konsantrasyonuna, foto başlatıcı konsantrasyonuna ve UV 1şığın yoğunluğuna bağlıdır. Bu parametrelerin doğruluğu için yapılan bir çalışmada, düşük UV yoğunluklarının hem düşük hem de yüksek foto başlatıcı konsantrasyonlarında daha iyi hücre canlılığı sergilediği ortaya konulmuştur. Bununla birlikte, oluşturulan hücre iskelelerinin de düşük sertliğe sahip olduğu gösterilmiştir. Bu çalışma ayrıca, optimum özelliklere sahip bir hücre iskelesi elde etmek için UV 1şığı ile maruz kalma süresinin de göz ardı edilebileceğini göstermiştir (Pepelanova ve ark., 2018).

Aljinat, algin veya alginik asit, kahverengi deniz yosunu alglerinden elde edilen doğal, negatif yüklü veya anyonik bir polisakkarittir. Polimer, sırasıly jelleşmeye katılan ve malzemeye esneklik kazandıran $\beta(1-4)$-D- mannuronik asit ve $\alpha$-(1-4)-L- guluronik asitten oluşur (Murphy ve Atala, 2014). Aljinat da jelatin gibi suda oldukça çözünürdür, ancak jel geçiş sıcaklığı $0{ }^{\circ} \mathrm{C}$ 'nin altındadır. Bu durum oda sıcaklığı veya fizyolojik sicaklıkta baskı yaparken herhangi bir fiziksel jelleşme durumunu ortadan kaldırır. Bununla birlikte, aljinat, 
$\mathrm{Ca}^{+2}$ gibi katyonlarla iyonik olarak çapraz bağlanabilir (Wang, 2019b). Polimerin karboksilat grupları hem zincir içi hem de zincir dışı şelatlanarak biyobasım ile elde edilen hücre iskelelerine stabilite kazandırmak için kullanılır (Liu ve ark., 2018). Park ve ark. (2017), CaCl kullanılarak katyonik çapraz bağlama ile düşük ve yüksek molekül ağırlıklı aljinat melez biomürekkep elde etmişlerdir.

Aljinatın biyouyumluluğu jelatine göre daha düşüktür, ancak in vivo uygulandiğında ters immünolojik reaksiyonlara neden olmaz. Ayrıca aljinat biyolojik anlamda parçalanabilir ve hücreye yapışmaz. Baskı sonrası elde edilen hücre iskelelerinin stabilitesi büyük ölçüde iki değerlikli katyon tarafından çapraz bağlanma oranına bağlıdır, ancak polimer ve iyon arasındaki iyonik etkileşimi kesintiye uğratabilen ortamın $\mathrm{pH}$ 'ına oldukça duyarlıdır (Liu ve ark., 2018). Uygulamalarda, aljinat çözeltisi önce hücre ve/veya biyoaktif moleküller ile birlikte yüklenir, basılır ve daha sonra $\mathrm{Ca}^{+2}$ püskürtülerek veya islatılarak çapraz bağlama katyonlarının devreye girmesi sağlanır (Wang, 2019b). Uygulamanın dezavantajı ise katyonlar zamanla hücre iskelelerinden sızıntı yapabilir, çapraz bağlanma tersine çevrilebilir ve elde edilen yapı uzun vadeli işlevsellik için katyonlar ile yeniden işlem gerektirebilir (Stanton ve ark., 2015). Aljinatta basılan yapının işlevselliği, polimer konsantrasyonuna, hücre yoğunluğuna ve çapraz bağlanma derecesine bağlıdır. Aljinat, karaciğer, kalp, kemik ve kıkırdak gibi birçok farklı dokunun biyobasımında başarıyla kullanılmıştır (Lee ve Mooney, 2012).

Agaroz, denizde yaşayan kırmızı deniz yosunu alglerinden elde edilen başka bir doğal polisakkarittir. $\beta$-D galaktopiranoz ve 3,6-anhidro- $\alpha$-L-galaktopiranoz bloğu olan tekrarlanan agarobiozdan oluşur (Wang, 2019a). Hücre iskelelerinde kullanılmak için oluşturulan modele oldukça iyi mekanik destek sağlar ve yaklaşık $30-45^{\circ} \mathrm{C}$ jelleşme sıcaklığına sahiptir (Liu ve ark., 2018). Fan ve ark. (2016), matrigel ve agarozun hibrit bir biyo-bağlantısını geliştirmişlerdir. Agarozun temelde kullanım amacı mürekkebin basılabilirliğini iyileştirmek ve basılı yapıların mekanik özelliklerini arttırmaktır. Bahsi geçen çalışmada da bu amaçla kullanılmıştır. Jelleşme sıcaklığı ise polimerin konsantrasyonuna bağlıdır. Agaroz yüksek düzeyde biyouyumlu olmasına rağmen sitoyapışkan değildir (Mao ve ark., 2017).

Diğer önemli doğal polimer, tüm doku ECM'sinin ana bileşeni olan, oldukça biyouyumlu ve sito-yapışkan bir malzeme olan kolajendir (Elvevold ve ark., 2008). Jelatin gibi, kolajen de hücre yapışmasını, çoğalmasını, göçünü ve farklılaşmasını destekleyen Arg-Gly-Asp motifini içerir (Liu ve ark., 2018). Kolajenin biyo-bağa dâhil edilmesi biyobasımlı yapının anjiyogenezini ve vaskülarizasyonunu arttırdığ1 gösterilmiştir (Kreimendahl ve ark., 2017; Yang ve ark., 2018). Kolajenin çapraz bağlanma özelliği $\mathrm{pH}$ ve sıcaklıktaki değişiklikler ile kolayca sağlanabilir. Ancak fizyolojik sıcaklıkta jelleşme süresi yaklaşık olarak 30 dakika sürebilir. Kolajenin en önemli özelliği ise özellikle in vivo ortamda yüksek oranda biyolojik olarak parçalanabilir olmasıdır (Stratesteffen ve ark., 2017). Bu özelliği, 3 boyutlu hepatorganoid oluşturulurken kolajen kullanımında bir kısıtlamaya neden olabilir (Gopinathan ve Noh, 2018).

Doğrusal bir polisakkarit olan selüloz da biyomürekkep olarak iki farklı biçimde kullanılmaktadır. Birincisi, metilasyon derecesine bağlı olarak son derece ayarlanabilir özelliklere sahip olan ve fizyolojik sıcaklığın altında jel oluşturabilen karboksimetil selülozdur. İkincisi, temelde nano yapılı selüloz olan ya kristal ya da elyaf biçiminde olan nanoselülozdur (Muller ve ark., 2017). Nanoselüloz, kıkırdak rejenerasyonu için yapıların biyolojik olarak yazdırılmasında kapsamlı ve başarılı bir şekilde kullanılmıştır.

Agaroz gibi selüloz da biyouyumludur ancak sito-yapışkan değildir. En önemli avantajı ise selülozun biyolojik olarak parçalanmamasıdır ve bu da onu uzun süreli uygulama için verimli k1lar (Markstedt ve ark., 2017). Karaciğerin 3 boyutlu biyobasımında kullanılan bir diğer önemli polimer de kitosandır. Kitosan, kabuklu deniz canlılarından elde edilen kitinin deasetilasyonuyla elde edilen bir polisakkarittir. Biyouyumludur fakat sito-uyumlu değildir, biyolojik olarak parçalanabilir ve antibiyotik özelliği gösterir. Bununla birlikte, yetersiz mekanik özellikler (örn. kırılganlık) ve jelleşme yeteneği 3 boyutlu biyobasım için kullanımında dezavantaj oluşturur (Liu ve ark., 2018).

\section{Sentetik polimerler}

Birçok üç boyutlu basım için uygun sentetik polimer mevcuttur. Özellikle polietilen glikol (PEG), polikaprolakton (PCL) ve poli (laktik-ko-glikolik asit) (PLGA) esas olarak hepatik yapıların biyobasımı için kullanılır. En çok karaciğer yapılarında kullanılanı ise PEG hidrojelleridir, PCL ve PLGA ise daha çok yumuşak dokulara benzer yüksek su tutma kapasitesi gösteren dokularda kullanılır. $\mathrm{Bu}$ polimerler ayarlanabilir mekanik özelliklere sahiptirler ve bu nedenle hem sert (örn. kemik) hem de yumuşak (örn. karaciğer) dokuları tasarlamak için kullanılabilir (Gopinathan ve Noh, 2018).

Karaciğerin biyobasımı için en yaygın olarak kullanılan sentetik polimer, poli etilen oksit (PEO) olarak da bilinen PEG'dir. PEG, suda mükemmel çözünürlüğe sahip, Amerika Birleşik Devletleri Gıda ve İlaç Dairesi (FDA) onaylı bir polimerdir (Wang, 2019a). Aynı zamanda biyouyumludur ve immünojenik değildir. Sito-yapışkan olmasa bile PEG'in terminal hidroksil grupları, polimerin çapraz bağlanmasını sağlamak için kimyasal olarak akrilat, karboksilat ve/veya tiyol şeklinde tasarlanabilir. Mekanik mukavemet, çapraz bağlanma derecesi ile kontrol edilebilir. PEG çözeltisinin viskozitesi yalnızca moleküler ağırlığa bağlıdır. Bundan dolayı ekstrüzyon esaslı baskı ve mürekkep püskürtmeli baskıda kullanılacak PEG çözümleri ile yüksek viskozite elde edilemez (Gopinathan ve Noh, 2018). Diğer bir popüler sentetik polimer ise non-toksik, biyouyumlu, hidrofobik, sito-yapışkan olmayan ve yavaş biyolojik bozunma gösteren PCL'dir. PCL kloroform, benzen ve toluen gibi organik çözücüler ile çözülebilir ve bu nedenle hücre yüklü yapıların doğrudan basılmasında kullanımı sınırlıdır (Gopinathan ve Noh, 2018). Dahası, yapıların sertliği nispeten yüksektir ve bu da karaciğer için uygun olmayabilir. Bunların dışında, laktik asit ve glikolik asidin lineer bir polyesteri olan PLGA da hepatik yapıların 3 boyutlu baskısı için kullanılmıştır. PLGA oldukça başarılı biyouyumluluk gösterir ve biyolojik olarak parçalanabilirliğe sahip FDA onaylı bir polimerdir (Wang, 2019a).

Polimerin bozunabilirliği, kopolimerdeki laktik ve glikolik asit içeriği değiştirilerek ayarlanabilir. Ayrıca glikolik asit oranı ne kadar yüksekse bozunma süresi de o kadar düşük olacaktır. Bununla birlikte, suyun PLGA için bir çözücü olarak kullanımını sınırlayan su içindeki ester bağlarının hızlı hidrolizine maruz kalır (Gopinathan ve Noh, 2018). Bu durum PLGA ile hücre yüklü yapıların ve hücre iskelelerinin oluşturulmasını sınırlar. 
Tablo 2

Son 5 yılda 3 boyutlu hepatik biyoyazıcı ile ilgili önemli çalışmaların özeti (Panwar ve Tan, 2016; Lewis ve ark., 2018; Sarkar ve ark., 2021).

\begin{tabular}{|c|c|c|c|c|c|}
\hline $\begin{array}{l}\text { Kullanılan } \\
\text { Biyoinkler }\end{array}$ & $\begin{array}{l}\text { Kullanılan } \\
\text { Hücre/ler }\end{array}$ & $\begin{array}{l}\text { Biyolojik Baskı } \\
\text { Süreci }\end{array}$ & Basılı Yapılar & Uygulama & Önemli Bulgular \\
\hline $\begin{array}{l}\text { Karaciğer } \\
{ }^{1} \text { dECM jelatin }\end{array}$ & NIH3T3, HUVEC & $\begin{array}{l}\text { Mürekkep } \\
\text { püskürtmeli }\end{array}$ & $\begin{array}{c}\text { 2D ve 3B } \\
\text { karaciğer şekilli } \\
\text { yapılar }\end{array}$ & $\begin{array}{l}\text { Yapay doku/organ } \\
\text { yenilenmesi }\end{array}$ & $\begin{array}{l}\text { Gelişmiş basılabilirlik ve mekanik } \\
\text { özelliklere sahip dECM toz bazlı biyoink }\end{array}$ \\
\hline $\begin{array}{l}\text { Pluronic F127- } \\
\text { Aljinat }\end{array}$ & HepG2 / C3A & $\begin{array}{l}\text { Ekstrüzyon } \\
\text { esaslı }\end{array}$ & 3B kare yapı & $\begin{array}{l}\text { İlaç taraması için } \\
\text { in vitro model }\end{array}$ & $\begin{array}{l}\text { Öğretici sinyaller olmadan } \\
\text { biyobasımda 3B hepatik model }\end{array}$ \\
\hline Jelatin & Huh7 & $\begin{array}{l}\text { Ekstrüzyon } \\
\text { esaslı }\end{array}$ & $\begin{array}{c}\text { Farklı dikme } \\
\text { açılarına sahip 3B } \\
\text { kafes }\end{array}$ & $\begin{array}{l}\text { Gelişmiş } \\
\text { işlevselliğe sahip } \\
\text { in vitro hepatik } \\
\text { model }\end{array}$ & $\begin{array}{l}60^{\circ} \text { dikme açısına sahip iskeleler } \\
\text { artmış karaciğer fonksiyonları gösterdi }\end{array}$ \\
\hline $\begin{array}{l}{ }^{2} \text { PCL } \\
\text { Karaciğer } \\
\text { dECM; } \\
\text { kolajen }\end{array}$ & $\begin{array}{l}\text { HepG2, } \\
\text { BMMSC'ler }\end{array}$ & $\begin{array}{l}\text { Ekstrüzyon } \\
\text { esasli }\end{array}$ & $2 \mathrm{~B}$ ve $3 \mathrm{~B}$ desenler & $\begin{array}{l}\text { Hepatik doku } \\
\text { mühendisliği }\end{array}$ & $\begin{array}{l}\text { Optimum mukavemet ve farklılaştırma } \\
\text { kapasitesine sahip biyoink baskı yapıları }\end{array}$ \\
\hline $\begin{array}{l}\text { Aljinat-selüloz } \\
\text { nanokristaller }\end{array}$ & $\begin{array}{l}\text { Fibroblastlar, insan } \\
\text { hepatom hücreleri }\end{array}$ & $\begin{array}{l}\text { Ekstrüzyon } \\
\text { esaslı }\end{array}$ & 3B petek yapısı & $\begin{array}{l}\text { Hepatik doku } \\
\text { mühendisliği }\end{array}$ & $\begin{array}{l}\text { Mükemmel basılabilirliğe sahip } \\
\text { yeni selüloz bazlı biyoink }\end{array}$ \\
\hline${ }^{3}$ PLGA & Aselüler & $\begin{array}{l}\text { Ekstrüzyon } \\
\text { esaslı }\end{array}$ & $\begin{array}{l}\text { Tek kanallı kübik, } \\
\text { silindirik, dallı üç } \\
\text { kanallı yarım küre }\end{array}$ & $\begin{array}{l}\text { Karaciğer } \\
\text { rejeneratif } \\
\text { iskeleler }\end{array}$ & $\begin{array}{l}\text { Düşük sıcaklıkta biriktirme üretim cihazı } \\
\text { kullanan PLGA çok kanallı iskeleler }\end{array}$ \\
\hline Jelatin-aljinat & $\begin{array}{c}\text { Birincil } \\
\text { hepatoselüler } \\
\text { karsinom hücreleri }\end{array}$ & $\begin{array}{l}\text { Ekstrüzyon } \\
\quad \text { esasli }\end{array}$ & 3B küp & $\begin{array}{l}\text { Kişiselleştirilmiş } \\
\text { tıp }\end{array}$ & $\begin{array}{l}\text { Tümerojenisitenin korunmasıyla in vitro olarak } \\
\text { kültürlenen 3B baskılı birincil hücreler }\end{array}$ \\
\hline $\begin{array}{l}\text { Jelatin-aljinat- } \\
\text { matrigel }\end{array}$ & $\begin{array}{l}\text { Birincil intrahepatik } \\
\text { kolanjiokarsinom } \\
\text { hücreleri }\end{array}$ & $\begin{array}{l}\text { Ekstrüzyon } \\
\text { esasli }\end{array}$ & 3B küp & $\begin{array}{l}\text { Kişiselleştirilmiş } \\
\text { tıp }\end{array}$ & $\begin{array}{l}\text { Antikanser ilaç testi için hastaya } \\
\text { özel 3B biyo baskılı model }\end{array}$ \\
\hline${ }^{4}$ GelMA & $\begin{array}{c}\text { HepG2 / C3A } \\
\text { sferoidleri }\end{array}$ & $\begin{array}{l}\text { Mürekkep } \\
\text { püskürtmeli }\end{array}$ & Sivı damlacık & Çipte organ & $\begin{array}{l}\text { Doğrudan biyoreaktör kültür haznesinde } \\
\text { basıllmış hepatik sfero yüklü biyonik }\end{array}$ \\
\hline $\begin{array}{l}\text { Kolajen I- } \\
\text { hyaluronan }\end{array}$ & $\begin{array}{c}\text { Lx2, birincil fetal } \\
\text { aktive hepatik yıldız } \\
\text { hücreleri }\end{array}$ & $\begin{array}{l}\text { Ekstrüzyon } \\
\text { esaslı }\end{array}$ & $\begin{array}{c}\text { Dört kollu } \\
\text { tekerlek yapısı }\end{array}$ & $\begin{array}{l}\text { In vitro ilaç } \\
\text { taraması, hastalık } \\
\text { modellemesi }\end{array}$ & $\begin{array}{l}\text { Ek işlevsellik için diğer bileşenleri birleştirme } \\
\text { becerisine sahip ayarlanabilir biyoink }\end{array}$ \\
\hline $\begin{array}{l}\text { Aljinat-selüloz } \\
\text { nanokristal-GelMA }\end{array}$ & NIH3T3, HepG2 & $\begin{array}{l}\text { Ekstrüzyon } \\
\text { esaslı }\end{array}$ & 3B petek yapısı & $\begin{array}{l}\text { Hepatik doku } \\
\text { mühendisliği }\end{array}$ & $\begin{array}{l}\text { İki hücrenin hassas konumlandırılmasıyla iki } \\
\text { hücreli karaciğer lobül-mimetik yapıları }\end{array}$ \\
\hline $\begin{array}{l}\text { Karaciğer dECM- } \\
\text { GelMA }\end{array}$ & $\begin{array}{l}\text { İnsan kaynaklı } \\
\text { hepatositler }\end{array}$ & $\begin{array}{l}\text { Dijital ışık } \\
\text { işleme }\end{array}$ & $\begin{array}{l}\text { İç dişli benzeri } \\
\text { yapı }\end{array}$ & Karaciğer ikamesi & $\begin{array}{l}\text { Yüksek çözünürlüklü dijital ş̧ık işlemeli baskı } \\
\text { ile uyumlu yeni biyoink }\end{array}$ \\
\hline Kolajen & $\begin{array}{l}\text { İnsan yağından } \\
\text { türetilmiş kök } \\
\text { hücreler (hASC'ler) }\end{array}$ & $\begin{array}{l}\text { Ekstrüzyon } \\
\text { esaslı }\end{array}$ & 3B küp & $\begin{array}{l}\text { Biyoyapay } \\
\text { karaciğer }\end{array}$ & $\begin{array}{l}\text { hASC kaynaklı hepatosit benzeri hücreler } \\
\text { karaciğer rejenerasyonuna müdahale eder }\end{array}$ \\
\hline Aljinat & $\begin{array}{l}\text { Fare birincil } \\
\text { hepatositleri, } \\
\text { mezenkimal kök } \\
\text { hücreler }\end{array}$ & $\begin{array}{l}\text { Ekstrüzyon } \\
\quad \text { esasl1 }\end{array}$ & 3B küp & $\begin{array}{l}\text { Hepatik doku } \\
\text { mühendisliği }\end{array}$ & $\begin{array}{l}\text { 3B biyobasımlı yapıda hepatik ve } \\
\text { kök hücrelerin birlikte kültürü }\end{array}$ \\
\hline Aljinat & $\begin{array}{l}\text { Fare kaynaklı } \\
\text { hepatositler }\end{array}$ & $\begin{array}{l}\text { Ekstrüzyon } \\
\text { esaslı }\end{array}$ & 3B küp & $\begin{array}{l}\text { Biyo yapay } \\
\text { organlar }\end{array}$ & $\begin{array}{l}\text { Hepatik hücre kaynağı olarak } \\
\text { fare kaynaklı hepatositler }\end{array}$ \\
\hline Galaktosile aljinat & $\begin{array}{l}\text { Fare birincil } \\
\text { hepatositleri }\end{array}$ & $\begin{array}{l}\text { Mürekkep } \\
\text { püskürtmeli }\end{array}$ & Jel levha & $\begin{array}{l}\text { Hepatik doku } \\
\text { mühendisliği }\end{array}$ & $\begin{array}{l}\text { Bask1 sırasında hücrelerin kontrollü } \\
\text { 3B geometrik düzenlemesi }\end{array}$ \\
\hline Aljinat & $\begin{array}{l}\text { Fare birincil } \\
\text { hepatositleri }\end{array}$ & $\begin{array}{l}\text { Ekstrüzyon } \\
\text { esaslı }\end{array}$ & 3B küp & $\begin{array}{l}\text { Hepatik doku } \\
\text { mühendisliği }\end{array}$ & $\begin{array}{l}\text { Birincil hepatositlerin uzun vadeli } \\
\text { canlıllğı ve işlevselliği }\end{array}$ \\
\hline Aljinat & HepG2 & $\begin{array}{l}\text { Ekstrüzyon } \\
\text { esaslı }\end{array}$ & 3B küp & Rejeneratif tıp & $\begin{array}{l}\text { HepG2'nin geliștirilmiş } \\
\text { karaciğer fonksiyonları }\end{array}$ \\
\hline Atelocollagen & $\begin{array}{l}\text { Siçan birincil } \\
\text { hepatositleri, } \\
\text { HUVEC, insan } \\
\text { akciğer fibroblastı }\end{array}$ & $\begin{array}{l}\text { Ekstrüzyon } \\
\text { esasli }\end{array}$ & 3B küp & Rejeneratif tıp & $\begin{array}{l}\text { Parankimal ve parankimal olmayan } \\
\text { hücrelerin ortak kültürü, anjiyogenez }\end{array}$ \\
\hline $\begin{array}{l}\text { Karaciğer dECM- } \\
\text { GelMA }\end{array}$ & HepLL, Çakı-1 & Litografi & $\begin{array}{l}\text { Mikroakışkan } \\
\text { cihaz }\end{array}$ & $\begin{array}{l}\text { Tümör ilerleme } \\
\text { modeli }\end{array}$ & $\begin{array}{l}\text { Böbrek kanseri hücrelerinin karaciğere } \\
\text { göçü için çip üzerinde metastaz }\end{array}$ \\
\hline $\begin{array}{l}\text { İnsan akciğer } \\
\text { dECM-aljinat- } \\
\text { jelatin }\end{array}$ & HepaRG & $\begin{array}{l}\text { Ekstrüzyon } \\
\text { esaslı }\end{array}$ & 3B küp & $\begin{array}{l}\text { Enfeksiyon ve } \\
\text { bulaşma } \\
\text { çalışmaları }\end{array}$ & $\begin{array}{l}\text { Baskılı doku modeli, aksi takdirde sferoid } \\
\text { modellerde elde edilemeyen kapsamlı } \\
\text { transdüksiyona izin verdi }\end{array}$ \\
\hline NovoGel & $\begin{array}{c}\text { Birincil } \\
\text { kriyoprezerve insan } \\
\text { hepatositleri, hepatik } \\
\text { yıldız hücreleri, } \\
\text { HUVEC }\end{array}$ & $\begin{array}{l}\text { Ekstrüzyon } \\
\quad \text { esasli }\end{array}$ & $\begin{array}{l}\text { İki bölmeli } \\
\text { düzlemsel } \\
\text { geometri }\end{array}$ & $\begin{array}{l}\text { In vitro hepatik } \\
\text { model }\end{array}$ & $\begin{array}{l}\text { Her hücre tipinin belirlenen yerlere } \\
\text { hassas bir şekilde iletilmesi, doğal } \\
\text { doku yapısının tekrarlanması }\end{array}$ \\
\hline
\end{tabular}

${ }^{1} \mathrm{dECM}$ : hücresizleştirilmiş hücre dışı matris, ${ }^{2} \mathrm{PCL}$ : polikaprolakton, ${ }^{3} \mathrm{PLGA}$ : poli (laktik asit-ko-glikolik asit), ${ }^{4}$ GelMA: jelatin metakrilat. 


\section{Hücresizleştirilmiş matris}

Hücresizleştirilmiş karaciğer ekstraselüler matrisi, karaciğerin kimyasal ve/veya enzimatik olarak hücresizleştirilmesiyle elde edilen doğal biyomalzemelerin ve moleküllerin bir karışımıdır (Pati ve ark., 2014). Bu şekilde elde edilen hücresizleştirilmiş ECM (dECM) liyofilizasyon ile toz haline getirilebilir ve hücre yüklü yapıların basılması için biyolojik tamponlar veya farklı biyomalzemeler ile çözülebilir (Jang ve ark., 2016). Hücresizleştirme yöntemi doğal kimyasal bileşimi, mikrogeometrisi ve karaciğerin büyüme faktörleri gibi biyomoleküllere sahip olması ve ayrıca in vitro hepatik hücrelere in vivo benzeri bir ortam sağlayabilen bir biyomalzeme olması ile güvenli bir mikroçevre sunar. Genellikle dECM, fizyolojik pH ve sıcaklıkta jelleşmeye başlar ve bu da 3 boyutlu baskıda kullanımı için uygun olduğunu gösterir. Ancak dECM solüsyonlarının düşük viskozitesi de dezavantajı olarak söylenebilir (Pati ve ark., 2014).

Karaciğerin ekstraselüler matrisi, Glisson kapsülünü, merkezi damarları, portal yollarını ve sinüzoid duvarlarını oluşturan yalnızca \%3'lük bir karaciğer alanını kapsar. Karaciğer ekstraselüler matrisinde en çok bulunan bileşen, tip I, III ve V'in de mevcut olduğu kolajen IV'tür (Jang ve ark., 2016; Pati ve ark., 2015). Bunun dişında glikoproteinler (fibronektin, laminin vb.) ve proteoglikanlar (heparin, hyaluronik asit, kondroitin sülfat vb.) da karaciğer ekstraselüler matrisinin ana bileşenleridir. Karaciğer dECM, biyomalzeme olarak mükemmel bir aday gibi görünse de zayıf şekil koruma özelliğ ve hızlı biyolojik bozunma gibi nedenlerden dolayı büyük yapıları basmak ve uzun vadeli denemeler için kullanımını kısıtlar. Dahası, dECM'nin en yaygın kaynağı ksenojeniktir yani in vivo çalışmalarda immünojenik bir tehdit oluşturabilir (Wang, 2019b; Jang ve ark., 2017). Bu da, hücresel yapılar arasında immünojenik reaksiyon ortaya çıkarabileceği anlamına gelir. $\mathrm{Bu}$ verilere rağmen, hücresizleştirilmiş karaciğer matrislerinin hücre yüklü 3 boyutlu hepatik yapıları oluşturmak için mükemmel bir biyomalzeme adayı olduğu yadsınamaz.

\section{3 boyutlu baskılı karaciğer yapılarında son çalışmalar}

Polimerlerin neredeyse hepsi biyo-bağ oluşturmak için istenen tüm özellikleri sergileyemez. Dolayısıyla, 3 boyutlu hepatik baskı üzerine yapılan çalışmaların çoğu, optimum şartları sağlaması için iki ya da daha çok biyomalzemenin uygun formlarda birleştirilmesi ile kullanılır (Jang ve ark., 2016). Son 5 yılda yayınlanan 3 boyutlu hepatik biyobasıma ilişkin başlıca çalışmaların özeti Tablo 2'de sunulmuştur.

Biyobasım hepatik yapıların biyouyumlu yapılar olması için gelişiminde birçok yaklaşım kullanılmıştır. Kim ve ark. (2020), dECM toz temelli biyomalzemesi, domuz dECM mikropartiküllerinin hyaluronik asit, fibrinojen ve biyoaktif bileşenler içere jelatinde karıştırılmasıyla hazırlanmıştır. dECM biyomalzemesinin yüksek viskozite ve kesme inceliği özellikleri hem daha kolay izlenebilir olmasını hem de ECM mikropartiküllerinin eşit dağılımını sergileyebilir.

Biyomalzemenin üç boyutlu basılabilirliğini sergileyen ve bu zamana kadar yapılan en büyük orantılarına sahip yapı elde edilmiş oldu. Ayrıca, elde edilen biyomalzeme insan karaciğeri ve endotelyal hücreler ile sito-uyumluydu. Bu nedenle çok hücreli karaciğer yapısı için potansiyel bir kullanım alanı oluşturdu.

Gori ve ark. (2020), termoreponsif ve biyoinert yarı sentetik aljinat-pluronik biyomalzemeyi bir pluronik şablon tarafından sağlanan yüksek şekil uygunluğuna sahip hepatik yapıları basmak ve ısıl tepkisel yapı ile jelleşmeyi kontrol etmek için kullanmışlardır. Ortaya çıkan hepatik yapı, asetaminofene karşı gelişmiş hepatik işlevsellikler ve duyarlılık sergilemiş, böylece fizyolojik olarak daha ilgili özellikler göstermiştir. Lewis ve ark. (2018), jelatin biyomalzemesi ile baskılı yapının geometrik mimarisi ve gözenek boyutunun siralı olmasını dikkate almışlardır. Yapı, farklılaşmış hepatositler olarak bilinen Huh7 hücrelerinin proliferasyonunda duraklama sergilememiş, ancak albümin sekresyonu ve MRP2 protein ekspresyonu gibi gelişmiş hepatik özellikler sergilemiştir. Lee ve ark. (2016) ise karaciğer dECM kullanılarak bir biyomalzeme ile yüksek doğrulukta yapılar hazırlamışlardır. Yapı, mezenkimal kök hücrelerin (MSC'ler) hepatik kökene farklılaşmasını sergilemesinin yanı sıra ticari olarak temin edilebilen kolajen ile karşılaştırıldığında insan hepatoselüler karsinom, HepG2 hücrelerinin daha fonksiyonel özelliklerini sergilemiş oldu. $\mathrm{Bu}$ çalışma, sadece dECM'yi biyomalzemenin bir bileşeni olarak kullanarak kararlı ve fonksiyonel hepatik yapılar üretilmesine olanak sağladığı için çığır açan bir çalışma olarak kabul edilmiştir. Wu ve ark. (2018), kolaylıkla şekil verebilme özelliği gösteren selüloz nanokristaller ve aljinattan oluşan bir hibrit biyo-bağ geliştirmişlerdir. Elde edilen hibrit biyomalzeme, ekstrüzyon temelli bioprinter ile $100 \mu \mathrm{m}$ çapındaki bir nozuldan rahatlıkla ekstrüde edilebilmektedir. Biyomalzeme ile hepatik hücrelerin ve fibroblastların ortak kültür koşullarında basılabildiği gösterilmiştir. Wang ve ark. (2017), farklı baskı parametrelerinin optimizasyonunu çalışmışlardır. PLGA tabanlı 3B baskılı iskeleler için polimer konsantrasyonu, nozül hızı ve ekstrüzyon hızı istenilen şekilde hazırlanmasına rağmen, duvar kalınlığı ve şekillendirmeye sahip karaciğer yapılarının sentezi noktasında başarılı bulunmamıştır. Çalışma, üç boyutlu yapının kalitesiyle ümit verici, fakat performansı ve hücrelerle uyumluluğu noktalarında istenilen doğrulukta olmadığ anlaşılmıştır.

Doku mühendisliği ile elde edilen karaciğer yapılarının in vitro temel uygulaması için polimerik biyo-bağlantılar sayesinde 3 boyutlu yazdırılmış hepatik yapılar oluşturularak oldukça önemli adımlar atılmaktadır. Xie ve ark. (2021) tarafından yakın zamanda yapılan bir çalışmada, hepatoselüler karsinom hücreleri farklı hastalardan izole etmişlerdir ve jelatin-aljinat mürekkepler kullanılarak biyobasım yapılar üzerinde uzun süreli kültür oluşturulmuştur. Biyolojik olarak basılmış yapılar, hastaların genetik özelliklerini korumaktadır ve böylece kişiselleştirilmiş tıp için önemli bir adım atılmıştır. İnvazif ve metastatik özellikler ile antikanser ilaçlara yanıt üzerine yapılan çalışmalar, kişiselleştirilmiş tıbbın geliştirilmesi için umut verici sonuçlar göstermiştir (Mao ve ark., 2020a). HepG2/C3A sfero yüklü GelMA biyoink kullanarak bir çip üzerinde karaciğeri yazdırmak için bir biyo yazıcı ile ara yüzü oluşturulmuş bir perfüzyon biyoreaktör kullanılmıştır Platform, in vivo hayvan çalışmalarında kullanılarak karşılaştırılabilir ilaç yanıtının incelenmesinde karaciğere özgü işlevsellikler ve gen ekspresyonu göstermiştir. Kollajen I-hyaluronik asit hibrit biyobağlayıcısı, birincil insan hepatositlerinin ve karaciğer yıldızsı hücrelerinin ortak kültürünü oluşturmak için kullanılmıştır. Yapı, uzun süreli kültür süresi, artmış albümin salgısı ve üre sentezinin yanı sıra asetaminofene karşı değiştirilmiş yanıt sergilemiştir. Kişiselleş-tirilmiş ilaç için oluşturulan yapı faydalı olabilir, ancak detaylı araştrıma ve doğrulama gereklidir (Gaetani ve ark., 2015; Bhise ve ark., 2016).

3B baskılı karaciğer yapılarındaki kayda değer gelişmelerin her biri rejeneratif tıp uygulamalarıdır. Aşırı 
karaciğer hasarı durumunda rejenerasyonu için dış müdahale gereklidir. Ya karaciğer yenilenene kadar karaciğer fonksiyonlarını yerine getirmek için bir ex situ biyo-yapay karaciğer destek cihazı sağlanabilir ya da doku mühendisliği ile yapılmış bir karaciğer yapısının in vivo implantasyonu gerçekleştirilebilir (Bhise ve ark., 2016). Son zamanlarda oldukça önemli veriler sunan HepG2 hücre hattında yapılan bir çalışmada, aljinat, nanokristalin selüloz ve GelMA kullanılarak fibroblast ve hepatositlerin ortak kültürüne izin veren bir hibrit üç boyutlu hepatik yapı geliştirilmiştir. Fare embriyo fibroblast (NIH/3T3), sert bir matris oluşturan $\% 1$ aljinat, \%3 nanokristalin selüloz ve \%5 GelMA'dan (135ACG) oluşan hibrit bir biyo-bağ üzerine yüklenmiştir. \%4 GelMA üzerine yüklenen HepG2 daha sonra hepatik yapıya benzer bir hücre iskeletini yazdırmak için kullanılmıştır. NIH/3T3 ve HepG2 sferoidleri, hem homotipik hem de heterotipik bağlantılar oluşturması için sınırlandırılmıştır. Karaciğer hücreleri artmış karaciğer işlevselliği ile proliferasyonda tutukluk sergilemiştir (Wu ve ark., 2020).

Rejeneratif tıpta karaciğer benzeri yapının varlığı için yapılan çalışma bilim dünyasını oldukça heyecanlandırmıştır. Çalışmada, üç boyutlu bir biyobasım cihazı kullanılarak ve dijital 1 şı işleminden faydalanarak hepatik yapıyı basmak için GelMA-dECM polimer karışımı kullanılmıştır. İnsan kaynaklı hepatositler (HiHep), iç dişli benzeri bir yapı ve hücresel aktiviteler için yüksek bir yüzey alanı ile karaciğer mikro dokusuna basılmış hücre yüklü biyo-bağ oluşturmak için GelMA'ya ve domuz dECM bileşimine ilave edilmiştir. DECM, biyomalzemenin basılabilirliğini geliştirmiş ve ayrıca albümin sentezi ve kan üre nitrojen salgılanması ile ölçülen hücre canlılığ 1 ve işlevselliğini geliştirerek umut verici sonuçlar sergilemiştir (Mao ve ark., 2020b).

Lee ve ark. (2017) tarafindan yapılan bir çalışmada ise hepatik bloklar, insan adipoz hücrelerinin kolajen I biyomalzemesi ile 3 boyutlu yapı oluşturmuştur ve hepatosit benzeri hücrelere farklılaştırılmıştır. Akut karaciğer yetmezliği için indüklenen bir sıçanın implantasyonunda hücreler basılı yapıdan çıkarıldı ve 4 hafta sonra hepatik portal venlere yer değiştirmiştir. Serumda artan karaciğere özgü parametreler değerlendirildiğinde sıçanın karaciğer yetmezliği sorununda ortadan kalktığı bulunmuştur. Geliştirilen model, yapay karaciğer modellerine potansiyel bir alternatif olarak ortaya çıkmıştır. Kim ve ark. (2018) tarafından düşünülen üç boyutlu yapıda ise uzun süreli kültür koşulları gelişmiş hepatik işlevsellik (albümin salgısı ve üre sentezi) ve ilacın metabolik aktivitesinin birincil hepatositleri ve mezenkimal kök hücreleri (MSC'ler) kullanabilmek için aljinat biyomalzemesinin olumlu sonuçlar verebileceği düşünülmüştür. MSC'ler tarafından salgılanan parakrin molekülleri karaciğer fonksiyonlarını iyileştirdi ve 3 boyutlu yapı sferoidlere/organoidlere kıyasla daha az hipoksik stres göstermiştir. Fakat doku mühendisliği örneği olan bu çalışmanın ilaç taraması veya rejeneratif tıp uygulamaları için daha detaylı çalışmalar ile doğrulanması gerekmektedir. Kang ve ark. (2018), fare kaynaklı hepatosit benzeri hücreler (miHeps) ile çalışmışlardır. Aljinat kullanılarak elde edilen model bir hafta süreyle in vitro olarak kültürlendi ve daha sonra karaciğer fonksiyonlarının restorasyonunu sergileyen bir fare, karaciğer hasarı modeline in vivo implante edilmiştir.

Farklı bir çalışmaya imza atan Arai ve ark. (2017), baskılı birincil hepatositlerin polaritesini korumak için galaktosilealjinat biyo-bağının kullanımını deneysel çalışmalar ile göstermişlerdir. Aljinat veya hepatositlerin ortak kültürü, insan umbilikal ven endotel hücreleri ve bir PCL çerçevesinde kollajen ile basılmış insan akciğer fibroblastları ile basılan primer hepatositlerin ve HepG2 hücreleri ile elde edilen verilerde bildirilmiştir. Hepsi uzun süreli kullanılabilir ve gelişmiş hepatik özelliklere sahiptir, ancak yapıların entegrasyonu için doğrulanması gerekir (Lee ve ark., 2016; Kim ve ark., 2017).

Hepatik doku mühendisliği için önemli uygulamalar arasında yer alan dECM-GelMA hibrit bileşimi ile elde edilen basılı mikro doku kullanılarak böbrek kanserinin karaciğere ilerlemesini incelemek için bir çip üzerinde metastatis modeli geliştirilmiştir (Wang ve ark., 2020). Platform, tümör ilerlemesinin farklı aşamalarında antikanser ilaç dozajını tahmin etmek için kullanılabilir. Başka bir durumda, HepaRG hücrelerinin aljinat-jelatin-dECM bileşenleri ile bir biyoink oluşturulup basılmasıyla bir viral enfeksiyon modeli geliştirilmiştir. İnsan dECM'sinin eklenmesi, hücre yüklü biyoinkin basılabilirliğini ve HepaRG hücrelerinin hepatik işlevselliğini büyük ölçüde arttırmıştır. Biyolojik olarak basılmış hepatik yapı, insan adenovirüs 5 'in yanı sıra adeno bağlantılı virüs tarafından transdüksiyon üzerine RNA müdahalesi ile istenilen şekilde susturulan bir hedef gen olan siklofilin B tarafından başarıyla geliştirilmiş ve enfekte edilmiştir (Hiller ve ark., 2018). Bu nedenle, geliştirilen yapı, virüs enfeksiyonunun yanı sıra virüs aracılı gen terapisinin incelenmesinde de ikili bir platform görevi görmüştür.

\section{Sonuçlar}

Doğal ya da sentetik polimerlerin 3 boyutlu baskıda kullanılması, basılı yapının mekanik özelliklerini ve sertliğini kontrol etmek için çok iyi veriler sunmuştur. Ayrıca hücre yüklü biyo-bağlantıların hazırlanmasına izin vererek canlı yapıların üretilmesine yol açmıştır. Karaciğer gibi düşük sertliğe sahip yumuşak dokuların geliştirilmesinde büyük bir avantaj sağlamış ve karaciğerin karmaşık ve ayrıntılı yapısının neredeyse kopyalanmasına olanak sağlamıştır.

Doğal polimerler, biyolojik uyumluluğun en iyi sergilendiği polimerler olması nedeniyle doku mühendisliği çalışmaları için birçok fayda sağlar. 3 boyutlu hepatik yapılar için en yaygın kullanılan polimerler ise jelatin ve hücresizleştirilmiş matrislerdir. Bir organın doğal yapısında bulunan sayısız hücre ve ECM bileşeni, yapının yeniden yapılandırılmasında en büyük zorluklardan biridir. Bu nedenle biyomateryal seçiminde dikkat edilmesi gereken bu sınırlama çalışmaların en büyük sorunudur. Polimerlerin tek başına kullanılması, mekanik mukavemet, sitoadherans ve farklı hücre tiplerinin işlevlerini destekleme ve geliştirme yeteneği gibi istenen tüm özellikleri sağlayamamaktadır. $\mathrm{Bu}$ nedenle farklı polimerlerin ve diğer biyomateryal türlerinin karışımları ve kompozitleri kullanılarak istenilen özellikler elde edilmeye çalışılmaktadır. Buna rağmen, çözünürlük 3 boyutlu yapının elde edilmesinde en büyük engeldir, çünkü doku inceliklerini sergileyen yapı elde etmek oldukça zordur.

En yaygın olarak kullanılan baskı yönteminin ekstrüzyon esaslı olduğu bilinmektedir. Stereolitografi ve lazer destekli baskı gibi diğer 3 boyutlu baskı yöntemleri, aynı anda uzamsal çözünürlüğü iyileştirerek yüksek viskoziteli biyomürekkep ve yüksek hücre yoğunluğunu işlemek için araştırılabilir. Çalışmalar esas olarak hepatik karsinom, endotelyal ve fibroblast hücreleri ile çalışmanın sınırlı olduğunu iddia etmektedir. Daha fazla hücre çeşidinin dâhil edilmesi için daha fazla karaciğer hücresine ihtiyaç vardır. 
Bu derlemede öncelikle karaciğerin üç boyutlu biyobasımı ile elde edilen yapıların stabilitesini arttırmak daha sonra ise çeşitli doku mühendisliği uygulamaları için hepatik yapıları imal edebilmek başlıkları üzerinde durulmuştur. Kararlı ve dayanıklı yapıların basılmasında birçok başarı elde edilmiş olsa da, homotipik ve heterotipik hücre-hücre ve hücre-ekstraselüler matris etkileşimlerini teşvik eden ekstraselüler matris bileşenleri ve hücreler için karaciğerin ayrıntılı yapısını basmak için daha fazla araştırma ve geliştirmeye ihtiyaç vardır.

Doku mühendisliği uygulamaları temel olarak in vitro ilaç taraması ve hastalık modellerinin yanı sira ex situ biyo yapay karaciğer desteği ve in vivo implante edilebilir yapılar ile rejeneratif tıbbı içerir.

\section{Kaynaklar}

Arai, K., Yoshida, T., Okabe, M., Goto, M., Mir, T. A., Soko, C., ... \& Nakamura, M. (2017). Fabrication of 3D-culture platform with sandwich architecture for preserving liver-specific functions of hepatocytes using 3D bioprinter. Journal of Biomedical Materials Research Part A, 105(6), 1583-1592.

Bhise, N. S., Manoharan, V., Massa, S., Tamayol, A., Ghaderi, M. Miscuglio, M., ... \& Khademhosseini, A. (2016). A liver-on-a-chip platform with bioprinted hepatic spheroids. Biofabrication, $8(1)$, 014101.

Blaeser, A., Duarte Campos, D. F., Puster, U., Richtering, W., Stevens, M. M., \& Fischer, H. (2016). Controlling shear stress in 3D bioprinting is a key factor to balance printing resolution and stem cell integrity. Advanced Healthcare Materials, 5(3), 326-333.

Bogert, P. T., \& LaRusso, N. F. (2007). Cholangiocyte biology. Current Opinion in Gastroenterology, 23(3), 299-305.

Causa, F., Sarracino, F., De Santis, R., Netti, P. A., Ambrosio, L., \& Nicolais, L. (2006). Basic structural parameters for the design of composite structures as ligament augmentation devices. Journal of Applied Biomaterials and Biomechanics, 4(1), 21-30.

Colosi, C., Shin, S. R., Manoharan, V., Massa, S., Costantini, M., Barbetta, A., ... \& Khademhosseini, A. (2016). Microfluidic bioprinting of heterogeneous 3D tissue constructs using low-viscosity bioink. Advanced Materials, 28(4), 677-684.

Elvevold, K., Smedsrød, B., \& Martinez, I. (2008). The liver sinusoidal endothelial cell: a cell type of controversial and confusing identity. American Journal of Physiology-Gastrointestinal and Liver Physiology, 294(2), 391-400.

Fan, R., Piou, M., Darling, E., Cormier, D., Sun, J., \& Wan, J. (2016). Bioprinting cell-laden Matrigel-agarose constructs. Journal of Biomaterials Applications, 31(5), 684-692.

Gaetani, R., Feyen, D. A., Verhage, V., Slaats, R., Messina, E., Christman, K. L., ... \& Sluijter, J. P. (2015). Epicardial application of cardiac progenitor cells in a 3D-printed gelatin/hyaluronic acid patch preserves cardiac function after myocardial infarction. Biomaterials, 61, 339348.

Gauvin, R., Chen, Y. C., Lee, J. W., Soman, P., Zorlutuna, P., Nichol, J. W., ... \& Khademhosseini, A. (2012). Microfabrication of complex porous tissue engineering scaffolds using 3D projection stereolithography. Biomaterials, 33(15), 3824-3834.

Gopinathan, J., \& Noh, I. (2018). Recent trends in bioinks for 3D printing. Biomaterials Research, 22(1), 1-15.

Gori, M., Giannitelli, S. M., Torre, M., Mozetic, P., Abbruzzese, F., Trombetta, M., ... \& Rainer, A. (2020). Biofabrication of hepatic constructs by 3D bioprinting of a cell-laden thermogel: An effective tool to assess drug-induced hepatotoxic response. Advanced Healthcare Materials, 9(21), 2001163.

Hiller, T., Berg, J., Elomaa, L., Röhrs, V., Ullah, I., Schaar, K., ... \& Kurreck, J. (2018). Generation of a 3D liver model comprising human extracellular matrix in an alginate/gelatin-based bioink by extrusion bioprinting for infection and transduction studies. International journal of molecular sciences, 19(10), 3129.

Hospodiuk, M., Dey, M., Sosnoski, D., \& Ozbolat, I. T. (2017). The bioink: A comprehensive review on bioprintable materials. Biotechnology advances, 35(2), 217-239.

Jang, J., Kim, T. G., Kim, B. S., Kim, S. W., Kwon, S. M., \& Cho, D. W.
Günümüzde ise esas olarak kişiselleştirilmiş doku mühendisliği yapıları oluşturarak bireysel/hastaya özgü hücrelerin kullanımı için çalışmalara daha çok yer verilmektedir. Son olarak kök hücrelerin basılmasına ve bunların hepatik kökenine doğru farklılaşmasına daha fazla dikkat çekilmelidir.

Çıkar çatışması: Yazar herhangi bir çıkar çatışması olmadığını beyan eder.

Etik beyanı: Bu çalışmada, yazar, hiç bir insan ya da hayvan denek kullanılmadığını ve Etik Kurul iznine gerek olmadığını beyan eder.

(2016). Tailoring mechanical properties of decellularized extracellular matrix bioink by vitamin B2-induced photo-crosslinking. Acta Biomaterialia, 33, 88-95.

Jang, J., Park, H. J., Kim, S. W., Kim, H., Park, J. Y., Na, S. J., ... \& Cho, D. W. (2017). 3D printed complex tissue construct using stem cellladen decellularized extracellular matrix bioinks for cardiac repair. Biomaterials, 112, 264-274.

Kang, H. W., Lee, S. J., Ko, I. K., Kengla, C., Yoo, J. J., \& Atala, A. (2016). A 3D bioprinting system to produce human-scale tissue constructs with structural integrity. Nature Biotechnology, 34(3), 312-319.

Kang, K., Kim, Y., Jeon, H., Lee, S. B., Kim, J. S., Park, S. A., ... \& Choi, D. (2018). Three-dimensional bioprinting of hepatic structures with directly converted hepatocyte-like cells. Tissue Engineering Part A, 24(7-8), 576-583.

Kim, M. K., Jeong, W., Lee, S. M., Kim, J. B., Jin, S., \& Kang, H. W. (2020). Decellularized extracellular matrix-based bio-ink with enhanced 3D printability and mechanical properties. Biofabrication, 12(2), 025003.

Kim, Y., Kang, K., Jeong, J., Paik, S. S., Kim, J. S., Park, S. A., ... \& Choi, D. (2017). Three-dimensional (3D) printing of mouse primary hepatocytes to generate 3D hepatic structure. Annals of Surgical Treatment and Research, 92(2), 67-72.

Kim, Y., Kang, K., Yoon, S., Kim, J. S., Park, S. A., Kim, W. D., ... \& Choi, D. (2018). Prolongation of liver-specific function for primary hepatocytes maintenance in $3 \mathrm{D}$ printed architectures. Organogenesis, 14(1), 1-12.

Kolesky, D. B., Homan, K. A., Skylar-Scott, M. A., \& Lewis, J. A. (2016). Three-dimensional bioprinting of thick vascularized tissues. Proceedings of the National Academy of Sciences, 113(12), 3179-3184.

Kreimendahl, F., Köpf, M., Thiebes, A. L., Duarte Campos, D. F., Blaeser, A., Schmitz-Rode, T., ... \& Fischer, H. (2017). Three-dimensional printing and angiogenesis: tailored agarose-type I collagen blends comprise three-dimensional printability and angiogenesis potential for tissue-engineered substitutes. Tissue Engineering Part C: Methods, 23(10), 604-615.

Lauschke, V. M., Hendriks, D. F., Bell, C. C., Andersson, T. B., \& Ingelman-Sundberg, M. (2016). Novel 3D culture systems for studies of human liver function and assessments of the hepatotoxicity of drugs and drug candidates. Chemical Research in Toxicology, 29(12), 19361955.

Lee, J. S., Yoon, H., Yoon, D., Kim, G. H., Yang, H. T., \& Chun, W. (2017). Development of hepatic blocks using human adipose tissue-derived stem cells through three-dimensional cell printing techniques. Journal of Materials Chemistry B, 5(5), 1098-1107.

Lee, J. W., Choi, Y. J., Yong, W. J., Pati, F., Shim, J. H., Kang, K. S., ... \& Cho, D. W. (2016). Development of a 3D cell printed construct considering angiogenesis for liver tissue engineering. Biofabrication, 8(1), 015007.

Lee, K. Y., \& Mooney, D. J. (2012). Alginate: properties and biomedical applications. Progress in Polymer Science, 37(1), 106-126.

Lewis, P. L., Green, R. M., \& Shah, R. N. (2018). 3D-printed gelatin scaffolds of differing pore geometry modulate hepatocyte function and gene expression. Acta Biomaterialia, 69, 63-70.

Liu, F., Chen, Q., Liu, C., Ao, Q., Tian, X., Fan, J., ... \& Wang, X. (2018). 
Natural polymers for organ 3D bioprinting. Polymers, 10(11), 1278.

Mao, B., Divoux, T., \& Snabre, P. (2017). Impact of saccharides on the drying kinetics of agarose gels measured by in-situ interferometry. Scientific Reports, 7, 41185.

Mao, Q., Wang, Y., Li, Y., Juengpanich, S., Li, W., Chen, M., ... \& Cai, X. (2020a). Fabrication of liver microtissue with liver decellularized extracellular matrix (dECM) bioink by digital light processing (DLP) bioprinting. Materials Science and Engineering: C, 109, 110625.

Mao, S., He, J., Zhao, Y., Liu, T., Xie, F., Yang, H., ... \& Sun, W. (2020b). Bioprinting of patient-derived in vitro intrahepatic cholangiocarcinoma tumor model: establishment, evaluation and anti-cancer drug testing. Biofabrication, 12(4), 045014.

Markstedt, K., Escalante, A., Toriz, G., \& Gatenholm, P. (2017). Biomimetic inks based on cellulose nanofibrils and cross-linkable xylans for 3D printing. ACS Applied Materials \& Interfaces, 9(46), 40878-40886.

Munaz, A., Vadivelu, R. K., John, J. S., Barton, M., Kamble, H., \& Nguyen, N. T. (2016). Three-dimensional printing of biological matters. Journal of Science: Advanced Materials and Devices, 1(1), 1-17.

Muller, M., Ozturk, E., Arlov, Ø., Gatenholm, P., \& Zenobi-Wong, M. (2017). Alginate sulfate-nanocellulose bioinks for cartilage bioprinting applications. Annals of Biomedical Engineering, 45(1), 210-223.

Murphy, S. V., \& Atala, A. (2014). 3D bioprinting of tissues and organs. Nature Biotechnology, 32(8), 773-785.

Panwar, A., \& Tan, L. P. (2016). Current status of bioinks for microextrusion-based 3D bioprinting. Molecules, 21(6), 685.

Park, J., Lee, S. J., Chung, S., Lee, J. H., Kim, W. D., Lee, J. Y., \& Park, S. A. (2017). Cell-laden 3D bioprinting hydrogel matrix depending on different compositions for soft tissue engineering: Characterization and evaluation. Materials Science and Engineering: C, 71, 678-684.

Pati, F., Ha, D. H., Jang, J., Han, H. H., Rhie, J. W., \& Cho, D. W. (2015). Biomimetic 3D tissue printing for soft tissue regeneration. Biomaterials, 62, 164-175.

Pati, F., Jang, J., Ha, D. H., Kim, S. W., Rhie, J. W., Shim, J. H., ... \& Cho, D. W. (2014). Printing three-dimensional tissue analogues with decellularized extracellular matrix bioink. Nature Communications, 5(1), 1-11.

Pepelanova, I., Kruppa, K., Scheper, T., \& Lavrentieva, A. (2018). Gelatinmethacryloyl (GelMA) hydrogels with defined degree of functionalization as a versatile toolkit for 3D cell culture and extrusion bioprinting. Bioengineering, 5(3), 55.

Sarkar, J., Kamble, S.C., Kashikar, N.C. (2021). Polymeric Bioinks for 3D Hepatic Printing. Chemistry, 3(1), 164-181.

Sarkar, J., Kamble, S.C., Patil, R., Kumar, A., Gosavi, S.W. (2020). Gelatin Interpenetration in Poly N-isopropylacrylamide Network Reduces the Compressive Modulus of the Scaffold: A Property Employed to Mimic Hepatic Matrix Stiffness. Biotechnology and Bioengineering, 117, 567579.

Stanton, M. M., Samitier, J., \& Sanchez, S. (2015). Bioprinting of 3D hydrogels. Lab on a Chip, 15(15), 3111-3115.

Stratesteffen, H., Köpf, M., Kreimendahl, F., Blaeser, A., Jockenhoevel, S., $\&$ Fischer, H. (2017). GelMA-collagen blends enable drop-on-demand 3D printablility and promote angiogenesis. Biofabrication, 9(4), 045002 .

Tamay, D. G., Dursun Usal, T., Alagoz, A. S., Yucel, D., Hasirci, N., \&
Hasirci, V. (2019). 3D and 4D printing of polymers for tissue engineering applications. Frontiers in Bioengineering and Biotechnology, 7, 164.

Turner, R., Lozoya, O., Wang, Y., Cardinale, V., Gaudio, E., Alpini, G., ... \& Reid, L. M. (2011). Human hepatic stem cell and maturational liver lineage biology. Hepatology, 53(3), 1035-1045.

Wang, X. (2019a). Advanced polymers for three-dimensional (3D) organ bioprinting. Micromachines, 10(12), 814 .

Wang, X. (2019b). Bioartificial organ manufacturing technologies. Cell Transplantation, 28(1), 5-17.

Wang, X., Rijff, B. L., \& Khang, G. (2017). A building-block approach to 3D printing a multichannel, organ-regenerative scaffold. Journal of Tissue Engineering and Regenerative Medicine, 11(5), 1403-1411.

Wang, X., Yu, X., Yan, Y., \& Zhang, R. (2008). Liver tissue responses to gelatin and gelatin/chitosan gels. Journal of Biomedical Materials Research Part A: An Official Journal of The Society for Biomaterials, The Japanese Society for Biomaterials, and The Australian Society for Biomaterials and the Korean Society for Biomaterials, 87(1), 62-68.

Wang, Y., Di Wu, G. W., Wu, J., Lu, S., Lo, J., He, Y., ... \& Wang, S. (2020). Metastasis-on-a-chip mimicking the progression of kidney cancer in the liver for predicting treatment efficacy. Theranostics, 10(1), 300-311.

Wang, Z., Abdulla, R., Parker, B., Samanipour, R., Ghosh, S., \& Kim, K. (2015). A simple and high-resolution stereolithography-based 3D bioprinting system using visible light crosslinkable bioinks. Biofabrication, 7(4), 045009.

Wang, Z., Kumar, H., Tian, Z., Jin, X., Holzman, J. F., Menard, F., \& Kim, K. (2018). Visible light photoinitiation of cell-adhesive gelatin methacryloyl hydrogels for stereolithography 3D bioprinting. ACS Applied Materials \& Interfaces, 10(32), 26859-26869.

Wells, R. G. (2008). Cellular sources of extracellular matrix in hepatic fibrosis. Clinics in Liver Disease, 12(4), 759-768.

Wu, Y., Lin, Z. Y. W., Wenger, A. C., Tam, K. C., \& Tang, X. S. (2018). 3D bioprinting of liver-mimetic construct with alginate/cellulose nanocrystal hybrid bioink. Bioprinting, 9, 1-6.

Wu, Y., Wenger, A., Golzar, H., \& Tang, X. S. (2020). 3D bioprinting of bicellular liver lobule-mimetic structures via microextrusion of cellulose nanocrystal-incorporated shear-thinning bioink. Scientific Reports, 10(1), 1-12

Xiao, W., He, J., Nichol, J. W., Wang, L., Hutson, C. B., Wang, B., ... \& Khademhosseini, A. (2011). Synthesis and characterization of photocrosslinkable gelatin and silk fibroin interpenetrating polymer network hydrogels. Acta Biomaterialia, 7(6), 2384-2393.

Xie, F., Sun, L., Pang, Y., Xu, G., Jin, B., Xu, H., ... \& Mao, Y. (2021). Three-dimensional bio-printing of primary human hepatocellular carcinoma for personalized medicine. Biomaterials, 265, 120416.

Yang, X., Lu, Z., Wu, H., Li, W., Zheng, L., \& Zhao, J. (2018). Collagenalginate as bioink for three-dimensional (3D) cell printing based cartilage tissue engineering. Materials Science and Engineering: C, 83, 195-201.

Yue, K., Trujillo-de Santiago, G., Alvarez, M. M., Tamayol, A., Annabi, N., \& Khademhosseini, A. (2015). Synthesis, properties, and biomedical applications of gelatin methacryloyl (GelMA) hydrogels. Biomaterials, 73, 254-271.

Cite as/Atıf şekli: Demirel, G. (2021). Karaciğer hücreleri ve organoidlerin üç boyutlu kültürlerinde kullanılmak üzere geliştirilmiş biyomalzemeler. Front Life Sci RT, 2(3), 111-119. 